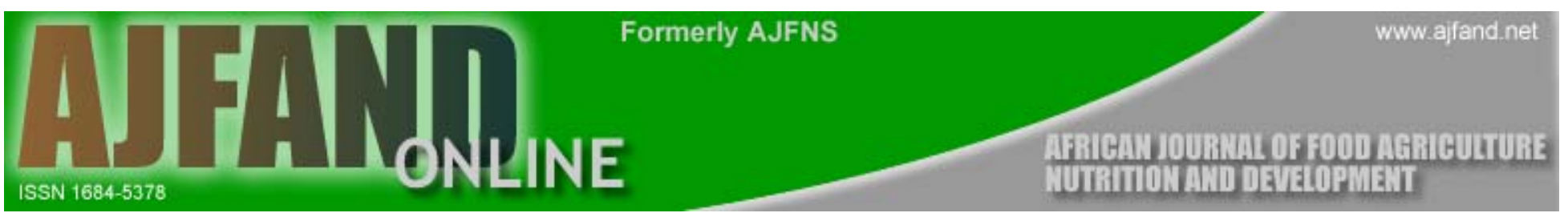

PEER REVIEWED ARTICLE 6

\title{
ROLE OF VITAMIN C (ASCORBIC ACID) ON HUMAN HEALTH- A REVIEW
}

\section{Walingo KM*}

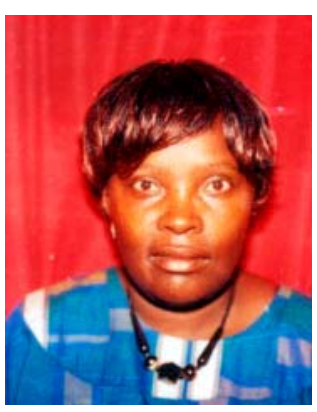

Walingo

*Dr Mary Khakoni Walingo, School Of Consumer Sciences \& Tech, Maseno University, Box 333, Maseno, Kenya. E-Mail: marywalingo@yahoo.com \& maelo@maseno.ac.ke 


\begin{abstract}
Vitamin C, also known as ascorbic acid, abounds in nature and is highly labile. It is a water-soluble vitamin that is lost in large amounts during food processing. It is a vitamin whose prescribed requirement across cultures is not uniform. For example , the prescribed requirement of vitamin $C$ in Great Britain is $30 \mathrm{mg} / \mathrm{day}$, while in the U.S.A., it is $60 \mathrm{mg} / \mathrm{day}$ and $100 \mathrm{mg} / \mathrm{day}$ in Japan. These variations are unusual and point to the need for further research to establish the acceptable RDAs for diverse populations. The RDA for vitamin $C$ should be more than the amount needed to prevent the occurrence of disease. Vitamin $C$ plays significant functions in the body that enhance its role in the health status of the human body. The biochemical functions of vitamin $C$ include: stimulation of certain enzymes, collagen biosynthesis, hormonal activation, antioxidant, detoxification of histamine, phagocytic functions of leukocytes, formation of nitrosamine, and proline hydroxylation amongst others. These functions are related to the health effects of vitamin $C$ status in an individual. In human health, vitamin $C$ has been associated with reduction of incidence of cancer, blood pressure, immunity, and drug metabolism and urinary hydroxyproline excretion, tissue regeneration. This vitamin is needed for the proper metabolism of drugs in the body through adequate hepatic mixed function oxidase system. Epidemiological data have revealed the preventive and curative role of vitamin $C$ on certain disease conditions in the body though controversies still persist. Vitamin $C$ is effective in protecting against oxidative damage in tissues and also suppresses formation of carcinogens like nitrosamines. There is an inverse relationship with blood pressure and both plasma vitamin $C$ and Vitamin $C$. Vitamin $C$ has a lowering effect on blood pressure, especially on systolic pressure more than a diastolic pressure. Low levels of plasma vitamin $C$ are associated with stroke and with an increased risk of all cause mortality. Increased consumption of ascorbic acid raises serum ascorbic levels and could decrease the risk of death.
\end{abstract}

KEY WORDS:

Vitamin C, cancer, blood pressure, drug metabolism, immunity

\title{
FRENCH
}

\section{RÉSUMÉ}

La vitamine $C$, appelée également acide ascorbique, abonde en nature et elle est fortement labile. C'est une vitamine soluble dans l'eau qui est perdue en grandes quantités pendant le traitement des produits alimentaires. Il s'agit d'une vitamine dont la prise prescrite dans les cultures n'est pas uniforme. Par exemple, la prise de la vitamine $C$ prescrite en Grande-Bretagne est de $30 \mathrm{mg} / \mathrm{jour}$, tandis qu'aux Etats-Unis elle est de $60 \mathrm{mg} /$ jour et de $100 \mathrm{mg} / \mathrm{jour}$ au Japon. Ces variations sont inhabituelles et elles indiquent la nécessité d'une recherche plus approfondie en vue 
d'établir les AQR (Apports Quotidiennement Recommandés) acceptables pour diverses populations. Les $\mathrm{AQR}$ en vitamine $\mathrm{C}$ devraient être supérieurs à la quantité requise pour prévenir l'apparition de maladies. La vitamine $C$ joue dans le corps des fonctions considérables qui augmentent son rôle dans l'état de santé du corps humain. Les fonctions biochimiques de la vitamine $C$ sont notamment la stimulation de certains enzymes, la biosynthèse des collagènes, l'activation des hormones, des antioxydants, la détoxification de l'histamine, des fonctions des phagocytes, des leucocytes, la formation de la nitrosamine, et l'hydroxylation proline, entre autres. Ces fonctions ont trait aux effets sanitaires de la teneur en vitamine $C$ dans un individu. En matière de santé humaine, la vitamine $C$ a été associée à la réduction de l'incidence du cancer et de la tension artérielle, à l'immunité, au métabolisme des médicaments et à l'excrétion hydroxyproline urinaire, ainsi qu'à la régénération des tissus. Cette vitamine est nécessaire pour un bon métabolisme des médicaments dans le corps par un système d'oxydase de fonctions mixtes hépatiques adéquates. Des données épidémiologiques ont révélé le rôle préventif et curatif de la vitamine $C$ sur certaines conditions de maladies dans le corps bien que des controverses persistent encore. La vitamine $C$ est efficace dans la protection contre des lésions oxydatives dans les tissus; elle supprime également la formation de cancérigènes tels que les nitrosamines. Il existe un rapport inverse entre la tension artérielle et la vitamine $C$ du plasma et la vitamine $C$. La vitamine $C$ a un effet de réduction sur la tension artérielle, plus particulièrement sur la pression systolique que sur la pression diastolique. Les niveaux peu élevés de la vitamine $C$ du plasma sont associés à la congestion cérébrale et à un risque élevé de toutes les causes de la mortalité. Une consommation élevée d'acide ascorbique augmente les niveaux ascorbiques du sérum et pourrait réduire les dangers de mort.

Mots-clés:

Vitamine $\mathrm{C}$, cancer, tension artérielle, métabolisme des médicaments, immunité.

\section{INTRODUCTION}

Ascorbic acid, commonly known as vitamin $\mathrm{C}$ plays significant functions in the human body, though its function at the cellular level is not very clear. Vitamin $\mathrm{C}$ is needed for collagen synthesis, the protein that serves so many connective functions in the body. Among the body's collagen-containing materials and structures are the framework of bone, gums and binding materials in skin muscle or scar tissue. Production of certain hormones and of neurotransmitters and the metabolism of some amino acids and vitamins require vitamin $\mathrm{C}$. This vitamin also helps the liver in the detoxification of toxic substances in the system, and the blood in fighting infections. Ascorbic acid is important in the proper function of the immune system. As an antioxidant, it reacts with 
compounds like histamines and peroxides to reduce inflammatory symptoms. Its antioxidant property is associated with the reduction of cancer incidences $[1,2]$.

The requirement for vitamin $\mathrm{C}$ for adults does not seem to be uniform across cultures. This may be a pointer to the need for cultural-specific requirements for the nutrient. It has now been appreciated that ascorbic acid functions in cellular reactions and processes. Epidemiological data now point to reduction of colds with increased consumption of foods rich in vitamin C [3]. People are tempted to over-consume vitamin $C$ because of its health benefits. Miniscule increases in blood vitamin $\mathrm{C}$ levels decrease the risk of death from all conditions [4]. This paper presents a review of epidemiological data on the role of ascorbic acid in certain human health conditions. Though there are many functions of vitamin $\mathrm{C}$, its role in health is discussed in relation to cancer, blood pressure, immunity, drug metabolism and urinary hydroxyproline excretion.

\section{Vitamin $\mathbf{C}$ and Cancer}

Cancer is a global public health problem with increased mortality levels. Though there are many types of cancers, the review presents a general picture of the role of ascorbic acid in cancer. Vitamin $\mathrm{C}$ is effective in protecting against oxidative damage in tissues, and also suppresses formation of carcinogens like nitrosamines [4]. The WHO estimated an increase of over 10 million new cases of cancer. Despite progress against some rare forms of cancer, the overall death rate has increased [5]. Though Vitamin $\mathrm{C}$ is cytotoxic to tumor cells but non-toxic to normal cells, conventional medicine favors more powerful and toxic chemotherapeutic agents. Many studies have shown that vitamin $\mathrm{C}$ intake is inversely related to cancer, with protective effects shown for cancer of the lung, breast, pancreas, stomach, cervix, rectum and oral cavity [6]. The authors found that the oxidation of guanine, a purine in DNA was significantly reduced after vitamin $\mathrm{C}$ supplementation, but the oxidation of adenine also a purine was significantly elevated. The reduced level in the oxidation of guanine suggests that vitamin $\mathrm{C}$ acts as an antioxidant [5]. Extensive in vitro and in vivo vitamin $\mathrm{C}$ tests to determine its ability to prevent the adverse effects of, decrease the resistance to and increase the effects of chemotherapeutic have been conducted [7]. Combination of vitamin $\mathrm{C}$ and vitamin $\mathrm{K}$ given prior to chemotherapy increased survival and the effects of several chemotherapeutic agents in a murine ascitic living tumor model [8]. Vitamin $\mathrm{C}$ has also been shown to be safe to be used concurrently with radiation [9]. Administration of Vitamin $\mathrm{A}, \beta$-carotene, $\mathrm{E}$ and $\mathrm{C}$ can reduce the incidence, and delay the progression of various cancers such as skin, those of the colon, stomach, esophagus, mammary glands and bladder $[1,4,10,11]$. Epidemiological studies have revealed an inverse relationship between the intake of vitamins $\mathrm{A}, \beta$-carotene, $\mathrm{C}$ and $\mathrm{E}$, and the incidence of different cancers in humans. There is a decrease in cancer incidence and risk, in population with high content of these vitamins in the plasma. Carcinogenesis is related to cell differentiation, progression and metabolism, and co llagen synthesis.

The basic mechanism for carcinogenesis is cell differentiation, because cancer develops when there is loss of cell differentiation. Vitamins $\mathrm{A}, \beta$-carotene, $\mathrm{E}$ and $\mathrm{C}$ have a profound influence on cell growth and differentiation. Vitamin $\mathrm{C}$ is a strong antioxidant 
that acts synergistically with Vitamin $\mathrm{E}$ as scavengers for free radicals in the body system, which are carcinogenic. Ascorbic acid, as sodium ascorbate exerts marked cytotoxic effects on several mammalian cells in culture. These effects are dose dependent. For example, Lupulescus [2] reported that vitamin C (upto $200 \mathrm{ug} / \mathrm{ml}$ ) did not cause any morphological changes in mouse melanoma, mouse neuroblastoma, rat glioma and mouse fibroblasts in culture. At high concentrations $(500-1000 \mathrm{ug} / \mathrm{ml})$, vitamin $\mathrm{C}$ was lethal for neuroblastoma cells. Cytotoxic effects are also cell dependent, being stronger in human melanoma as compared to mouse melanoma cells. It has been suggested that vitamin $\mathrm{C}$ induced cytotoxicity is mediated primarily by hydrogen peroxide formation at cell surface, or thin cells. Cytotoxic activity can also be mediated by presence of cupric ions $\left(\mathrm{Cu}^{2+}\right)$ in malignant melanoma cells that react with vitamin $\mathrm{C}$ and generate free radicals in solution. Vitamin $\mathrm{C}$ also reverses the chemically transformed cells to thin normal phenotype.

Ultra structure and cell surface studies of cancer cells following vitamin C administration revealed observed cytolysis, cell membrane disruption, mitochondrial alterations, nuclear and nucleolar reduction, and increased phagolysosome formation in cancer cells following vitamin $\mathrm{C}$ administration [10]. Cell surface changes such as cytolysis, increased collagen synthesis, and cell membrane disorganization were predominant, and increased apoptotic and phagocytic activity were also seen. Quantitative estimation of cell organelles revealed that vitamin $\mathrm{C}$ affects the intracellular organelle distribution, playing an important role in cyto-differentiation of cell cancer $[1,10]$. Hence, vitamins $\mathrm{A}, \mathrm{E}$ and $\mathrm{C}$ markedly affect the cancer cells differentiation by exerting direct cytotoxic effects, modifying membrane biogenesis, light and gap junction formation, Golgi's complex, autophagic and apoptotic activity, cell surface changes and sometimes reversing transformed cells to their normal cell type. This reversal is necessary in the reduction of possible cancer incidences.

Changes of DNA, RNA and protein synthesis have been associated with cell differentiation and proliferation. The mechanism of action, however, is not fully understood. It has been suggested that most of the metabolic effects are mediated by transcription and translation processes at the genome level. Further, vitamins A, E and C modulate DNA synthesis and gene expression in a similar manner to that of steroid hormones. These vitamins may affect chemical mutagenicity and cellular status [2]. By affecting DNA, RNA and proteins at specific sites that are targets of electrophiles, the vitamins can control cell replication rate, leading to an altered cell rearranged codons and translocation of specific genes, or oncogenes. The vitamins $\mathrm{A}, \mathrm{E}$ and $\mathrm{C}$ affect differently DNA, RNA and protein synthesis in cancer cells. Administration of vitamin $\mathrm{C}$ decreases DNA synthesis in the nuclei, RNA synthesis in the nucleoli, and proteins in cytoplasm of cancer cells. This inhibition of DNA, RNA and protein synthesis is accompanied by advanced ultra structural and cell surface changes, and will decrease progression of cancer.

Vitamin C plays an important role in collagen synthesis. Collagen is an extracellular protein synthesized intracellularly as tropocollagen by the fibroblasts, and contains amino 
acids prolines, glycine and lysine. The major reaction in collagen synthesis is hydroxylation of proline to 4-hydroxyproline. This provides proper structural configuration and stability of collagen. The enzyme 4-hydroxylase, which is a tetramer, catalyzes hydroxylation of proline and its genes are differently located in human chromosomes. In some experiments ascorbic acid and its analogues specifically enhanced the collagen synthesis almost four-fold in cultured human skin fibroblasts, by increasing the incorporation of $(3 \mathrm{H}-)$ proline into colagenase sensitive proteins. Lascorbate was found to be the most active compound, [2]. It is also possible that ascorbic acid can stimulate collagen synthesis by other mechanisms, independent of hydroxylation. Ascorbic acid induces lipid peroxidation and reactive aldehydes, a step required for collagen expression, collagen m-RNA levels, and collagen production in cultured human fibroblasts. Collagen gene expression is probably influenced by lipid perodixation, or through acetaldehyde formation, which consequently increases collagen gene transcription in cultured human fibroblasts. The mechanism by which vitamin $\mathrm{C}$ stimulates collagen gene expression is not very clear. Ascorbic acid can, therefore, stimulate collagen synthesis independent of proline hydroxylation by inducing lipid peroxidation. Ascorbic acid is thus the major vitamin regulating collagen synthesis, and provides stability to the procollagen single helix $[1,2]$

\section{Blood Pressure}

Elevated blood pressure is a powerful determination of cerebro-vascular and coronary disease. Great efforts have been made towards the detection and treatment of hypertension since the 1960s. Some of the observed decrease in cardiovascular disease over the period has been attributed to better control of blood pressure among diagnosed hypertensives. The importance of nutrition in control of blood pressure is well documented. Obesity, dietary sodium and alcohol are associated with lower or higher blood pressure. Higher intake of polyunsaturated fatty acids and magnesium have also been linked with lower blood pressure [12].

Inverse associations with blood pressure and both plasma vitamin $\mathrm{C}$ and vitamin $\mathrm{C}$ have been reported. A study of the relationship between fasting vitamin $\mathrm{C}$ and cerebrovascular disease risk factors revealed reduction in hypertension in men. Men with serum vitamin $\mathrm{C}$ of $0.5 \mathrm{mg} / \mathrm{dl}$ had a mean systolic pressure of $122 \mathrm{mmHg}$ compared with a mean of 113 $\mathrm{mmHg}$ for men with serum vitamin $\mathrm{C}$ of $0.9 \mathrm{mg} / \mathrm{dl}$, a relative difference of $-7 \%$. The same men had a similar difference in diastolic pressure of $78 \mathrm{mmHg}$ vs. $73 \mathrm{mmHg}-6 \%$ relative difference. Prevalence of hypertension was $7.5 \%$ in the low serum vitamin $\mathrm{C}$ group versus $1.0 \%$ among those with high levels of vitamin $\mathrm{C}$ [13]. An investigation to identify the association between BP plasma antioxidant vitamin revealed a significant trend for both systolic and diastolic pressure over qualities of plasma vitamin $\mathrm{C}$ with a $5 \%$ difference in systolic pressure and a $-4 \%$ difference in diastolic BP between highest and lowest quintiles of plasma vitamin C [14].

Similar significant negative trends between plasma vitamin $\mathrm{C}$ and both systolic and diastolic BP were observed in Chinese-American males and females aged 60-96 years who were not taking anti-hypertensive medication. The difference between mean systolic and diastolic BP levels in the highest and lowest quartiles were $-21 \mathrm{mmHg}(-14 \%)$ and - 
$8 \mathrm{mmHg}(-9 \%)$, respectively [15]. Vitamin $\mathrm{C}$ appears to have a lowering effect on systolic pressure, more than it has on diastolic pressure. Other negative correlation between dietary vitamin $\mathrm{C}$ intake and both systolic and diastolic BP [16] and negative association between BP, and vitamin $C$ intake and use of vitamin $C$ supplements in Honolulu Heart Study [17] have also been reported. Diastolic pressure was not associated with vitamin intake. Individuals consuming vitamin $\mathrm{C}$ in adequate quantities are likely to have lower BP. It is a cheaper form of supplementation for developing communities.

In a randomized placebo-controlled, cross-over trial on a mixed sample of 12 borderline hypertensives and 8 normotensives, there was reported a $4.4 \%$ drop in systolic BP between the placebo treatment and vitamin $\mathrm{C}$ treatment after four weeks of supplementation with 1 gram of vitamin C [18]. Vitamin C supplementation did not influence diastolic pressure. A cross-sectional study of the relationship of vitamin $\mathrm{C}$ intake and blood pressure in the elderly revealed relative differences in systolic and diastolic BP between subjects consuming $240 \mathrm{mg}$ /day compared to those consuming 60 $\mathrm{mg} /$ day were $-6.9 \%$ and $-6.6 \%$, respectively. The prevalence of elevated BP (systolic $160 \mathrm{mmHg}$ or diastolic $100 \mathrm{mmHg}$ ) was approximately $50 \%$ lower across this range vitamin C intake (60,60-119, 120-179, 180-239 240mg/day) [19]. Vitamin C thus appears to have a lowering effect on blood pressure of the elderly.

A prospective population-based cohort study of 2419 randomly selected middle aged men (42-60yrs) with no history of stroke was conducted to examine whether plasma vitamin C modifies the association between overweight and hypertension and stroke [20]. Men who had the lowest levels of plasma vitamin $\mathrm{C}$ were at a higher risk of developing any stroke compared to men who had the highest levels of plasma vitamin C. Hypertensive men who had the lowest vitamin $\mathrm{C}$ levels were at an increased risk for any stroke and so were overweight men with low plasma vitamin C. Low plasma vitamin $\mathrm{C}$ was associated with increased stroke risk.

An increase in the intake of vitamin $\mathrm{C}$ during the dietary fat reduction period could have accounted for a part of the blood pressure reduction $[14,15]$. Decreased plasma ascorbic acid levels were associated with reduced plasma concentrations of 6-ketoprostaglandin-F, the metabolite prostacylin. Thus dietary antioxidants enhance production of prostacyclin by scavenging free radicals and peroxides, which inhibit prostacylin synthetase at concentrations above a certain threshold. Thus vitamin $\mathrm{C}$ and blood pressure appear to be related, in that adequate dietary vitamin $\mathrm{C}$ could exert a reducing effect on blood pressure, and especially if dietary fat intake is reduced.

\section{Vitamin $\mathbf{C}$ and Immunity}

In stressful situations adrenal glands react by releasing hormones that trigger the "fight or flight" reaction. It has been indicated that $200 \mathrm{mg}$ of vitamin $\mathrm{C}$ a day may reduce the levels of stress hormones. Stress suppresses the immune system. Mega doses of vitamin $\mathrm{C}$ increase the levels of antibody that fights against germs and viruses in both stressed and unstressed rats, with greater antibody increase in the unstressed rats [21]. Stressed animals may need larger vitamin $\mathrm{C}$ doses for proper function of the immune system. 
Healing of wounds is characterized by synthesis of connective tissue, the major component of which is collagen. Ascorbic acid has important biological and metabolic functions, particularly with respect to its role in the biosynthesis of connective tissue [22]. Ascorbic acid is required for the hydroxylation of prolyl and lysl residues during collagen biosynthesis $[23,24,25]$. The supplementation of ascorbic acid is necessary to heal wounds since ascorbic acid may be oxidized during collagen synthesis [26].

Considerable evidence is available to document an interaction between vitamin $\mathrm{C}$ and phagocytic cells. Cells collected from blood, peritoneal or alveolan fluids, normally contain high (1-2 ug/mg protein) concentrations of vitamin $\mathrm{C}$ and in other in vitro conditions leukocytes can take up vitamin C. Neutrophils have been studied in vitro under conditions of vitamin $\mathrm{C}$ deprivation and excess [27, 28, 29]. Neutrophils from guinea pigs produce $\mathrm{H}_{2} \mathrm{O}_{2}$ and kill staphylococci as well as control cells. Ascorbate and dehydroascorbate are both utilized during phagocytic process [29]. Neutropholis may avoid poisoning themselves by absorbing extra ascorbic acid, which can neutralize antioxidants.

However, the glycolytic activity did not increase maximally in neutrophils from ascorbic guinea pigs and the stimulation of NADPH oxidase activity was depressed $[27,28]$. The addition of ascorbate to cultures of normal macrophages increases the cellular concentrations of cyclic GMP (cGMP) as well as HMP shunt [30]. Although the in vitro addition of ascorbate in very large amounts may inhibit $\mathrm{H}_{2} \mathrm{O}_{2}-$ myeloperoxidase-halide activity, it does not alter bacteriocidal capacity of cells. An increase in the in vitro concentrations of ascorbate increased phagocytic activity of cultural mouse peritoneal macrophages [31]. The addition of vitamin $\mathrm{C}$ cultures of neutrophil or macrophages increased their motility and chemotactic activity.

A defect in which a failure of the umbilicus to separate in newborn infants led to severe local and disseminated bacterial infection [32]. Two surviving had decreased neutrophil mobility that improved with the oral administration of ascorbic acid in doses of 200-800 $\mathrm{mg} /$ day, as well as in vitro addition of vitamin $\mathrm{C}$ to defective neutrophils. The ability of human neutrophils to kill Candida albicans occurs best at physiological in vitro concentrations of L-ascorbic acid. The locomotor functions, for example. random motion and chemotactic migration of neutrophils and macrophages are impaired in the absence of vitamin $\mathrm{C}$.

Vitamin C may influence the ability of certain cell lines to produce interferon when approximately stimulated. The addition of ascorbic acid to cultures of human embryo skin or to fibroblasts led to induction of interferon. Vitamin $\mathrm{C}$ appears to be required by thymus for the maintenance of certain cells, possibly certain reticular cells that are concerned with the production of thymic humoral factor. Thymic content of dehydroascorbate decreased in direct proportion to vitamin C. The hormone activity of thymic extracts correlated with thymic ascorbate and inversely with dehydroascorbate [33]. A prospective controlled study of students (18-32 years) in a technical training facility was conducted to assess the effect megadose vitamin $\mathrm{C}$ in preventing and relieving cold and flu symptoms [3]. The numbers of reports of cold and flu symptoms 
were recorded for both the test and control groups. Students in the test group were treated with hourly doses of $100 \mathrm{mg}$ of vitamin $\mathrm{C}$ for the first six hours and then three times thereafter while those in the control group were treated with pain relievers and decongestants. The reported cold and flu symptoms in the test group decreased by $85 \%$ more than the control group after the administration of the megadose vitamin $\mathrm{C}$.

\section{Drug Metabolism}

Vitamin $\mathrm{C}$ functions as a cofactor in hydroxylation reactions of collagen and catecholamine synthesis. It appears to be involved in a wide range of processes including macrophage function, carnitine synthesis and drug metabolism. Studies in guinea pigs have demonstrated that vitamin $\mathrm{C}$ deficiency alters the concentration and activity of components of the hepatic mixed function oxidase system and impairs the metabolism of a wide range of drugs. Much less is known about the effects of different vitamin $\mathrm{C}$ intakes on drug metabolism in humans. The few studies that have been conducted have not always been properly controlled and have yielded conflicting results [34, 35]. Discrepancies between studies may be due to the different drugs used and the extent of depletion achieved. This calls for the need to conduct research of vitamin $\mathrm{C}$ on particular drugs which could be financially and resourcefully expensive, though may clarify the role of vitamin $\mathrm{C}$ in drug metabolism.

Nutritional deficiencies have been shown to affect the kinetics of many drugs directly by altering their metabolism. Specifically vitamin $\mathrm{C}$ has been shown to influence the oxidative metabolism of a variety of drugs, including some oxidative demethylation processes in guinea pigs. A study of the influence of vitamin $\mathrm{C}$ on pharmacokinetics of caffeine in healthy elderly men reported that short-term alterations in vitamin $\mathrm{C}$ intake do not affect caffeine metabolism in elderly men [36]. In another study of the effects of vitamin $\mathrm{C}$ on the elimination of antipyrine in 14 healthy adults (24-25 years), added vitamin $C$ had no effect on the pharmacokinetics of antipyrine [37]. In contrast, there was an increased metabolic clearance of antipyrine after administration of vitamin $\mathrm{C}$ to non deficient young subjects and vitamin $\mathrm{C}$ deficiency elderly subjects [35, 37]. Assessment of the influence of subclinical ascorbic acid deficiency on drug metabolism revealed that pronounced ascorbic acid deficiency of relatively short duration does not alter antipyrine metabolism in man [38]. In contrast, vitamin $\mathrm{C}$ has repeatedly been shown to depress drug-metabolizing enzyme activity in guinea pigs [39, 40]. There is need to understand these effects in human populations.

Hepatic mixed function oxidase activity was measured in Gambian men during a period of low seasonal vitamin D intake after supplementation. Demythylation of methodyphelacetamide (methacetin) was followed using breath test, in which exhalation of ${ }^{13} \mathrm{C}$-enriched $\mathrm{CO}_{2}$ was measured following an oral dose of ${ }^{13} \mathrm{C}$-methacetin. Vitamin supplementation, sufficient to increase plasma levels significantly, did not influence methacetin metabolism. However, methacetin metabolism in unsupplemented men appeared normal in majority of cases. Hepatic tissue may not have been sufficiently depleted of vitamin $\mathrm{C}$ to impair the activity of the mixed function oxidase system. There is need to understand the effect of vitamin $\mathrm{C}$ on the mixed function oxidase system in hepatic tissues that are sufficiently depleted of the vitamin [41]. 


\section{Urinary Hydroxyproline Excretion}

Many clinical problems associated with ascorbic acid deficiency such as abnormalities of skeleton seen in infantile scurvy, lesions of gingiva, as well as impairment of wound healing of bony structures are related to collagen metabolism. Urinary excretion of hydroxyproline is considered to be a useful indicator of changes in metabolism of collagen because with the exception of the small amounts of hydroxyproline in elastin and component Uq (a hydroxy-proline rich in protein) in plasma no other protein contains a significant amount of this amino acid [42]. Collagen is much more abundant than these other hydroxyproline-containing proteins and comprises about one-third of the total body protein, which justifies the use of hydroxyproline in following changes in collagen turnover. There was reported an increase in urinary hydroxyproline by an average of $16 \%$ and $30 \%$ after first and second depletion periods, and decreased to baseline after supplementation with normal or high doses of ascorbic acid [43]. They concluded that urinary hydroxyproline excretion increases during human vitamin $\mathrm{C}$ deficiency but that this effect is not strong to provide a reliable marker of vitamin $\mathrm{C}$ deficiency.

\section{Conclusion}

Ascorbic acid is needed for various functions in the body, though its function at the cellular level remains unclear. Ascorbic acid is needed for collagen synthesis, a production of certain hormones and of neurotransmitters, metabolism of some amino acids and vitamins, detoxification of toxic substances in the body, and proper function of the immune system. The vitamin $\mathrm{C}$ requirements are not uniform across cultures, and hence need for further research in setting appropriate RDAs for vitamin $\mathrm{C}$.

Epidemiological data is increasing on the effect of vitamin $\mathrm{C}$ in cancer, blood pressure, immunity drug metabolism and urinary hydroxyproline excretion. Vitamin $\mathrm{C}$ is effective in protecting against oxidative damage in tissues and also suppresses formation of carcinogens like nitrosamines. High levels of serum ascorbic acid reduce blood pressure, especially systolic blood pressure. Low plasma vitamin $\mathrm{C}$ is associated with increased risk of stroke. Mega doses of vitamin $\mathrm{C}$ increases the levels of an antibody that fights against infections in both stressed and unstressed rats, with greater increase in the unstressed rats. Larger doses of vitamin $\mathrm{C}$ may be necessary for proper function of the immune system. Mega doses of vitamin $\mathrm{C}$ decreases the symptoms of cold and flu in humans. Though reports show that vitamin $\mathrm{C}$ influences the oxidative metabolism of a variety of drugs in guinea pigs, there is need to understand the effects in human populations. The role of vitamin $\mathrm{C}$ in the prevention and control of disease states is encouraging, since it is a cheaper way of enhancing vitamin $\mathrm{C}$ status through diets, instead of use of supplements that may be quite expensive. Vitamin $\mathrm{C}$ abounds in nature and thus in diets. However, it is highly labile and is destroyed through the methods of processing employed in food handling from harvesting through conservation and preparation stages. Principles of nutrient preservation through all these stages should be carefully applied. 


\section{References}

1. Lupulescu A Hormones and Vitamins in Cancer Treatment. 1990;149-211, CRC Press, BOCA Ration, Boston.

2. Lupulescu A The Role of Vitamins A, B Carotene, E and C in Cancer Cell Biology. Intern. Vit. Nutr. Res. 1993; 63:3-14.

3. Gorton HC and $\mathbf{K}$ Javis The Effectiveness of Vitamin $\mathrm{C}$ in Preventing and Relieving the Symptoms of Virus-induced Respiratory Infections, J. Man. Phys. Ther. Oct 1999; 22(8):530-3.

4. Simon JA, Hudes ES and JA Tice Relation of Serum Ascorbic Acid to Mortality among Adults. J. Am. Col. Nutr. June 2001; 20(3).

5. Calvino $\mathbf{N}$ and $\mathbf{S}$ Levine Vitamin $\mathrm{C} \&$ Cancer-Storm of Controversy: The Definitive Scientific Evidence Demonstrating Efficacy and Safety of Vitamin C for Cancer Treatment. www.positivehealth.com/permit/articles/cancer/calvino71.htm

6. Block G Epidemiological Evidence Regarding Vitamin $\mathrm{C}$ and Cancer. Am. J. Clin. Nutr. 1999; 54 (6): 1305-1314.

7. Shimpo $\mathbf{K}$, Nagatsu $\mathbf{T}$ and $\mathbf{T}$ Kyamada Ascorbic Acid and Adriamycin Toxicity. Am. J. Clin. Nutr. 1991; 54:1298-1305s.

8. Taper HS, Gerlache DJ and M Hans Non-toxic Potentiation of Cancer Chemotherapy by Combined Vitamin $\mathrm{C}$ and $\mathrm{K} 3$ Vitamin Pre-treatment. Int. J. Cancer. 1987:40: 575-579.

9. Taper HS, Keyeux A and M Roberfroid Potentiation of Radiotherapy by Nontoxic Pretreatment with Combined Vitamins C and K3 in Mice Bearing Solid Transplantable Tumor. Anticancer. Research. 1996; 16:499-504.

10. Hanck AB Vitamin C and Cancer. Progr. Clin. Biol. Res. 1988;259:307-320

11. Lupulescu A Ultra Structure and Cell Surface Studies of Cancer Cells Following Vitamin C Administration. Exp. Toxicol. Pathol. 1992; 44:3-9.

12. Pietinen $\mathbf{P}$ and $\mathbf{A}$ Aro The Role of Nutrition in The Prevention and Treatment of Hypertension. Adv. Nutr. Res. 1990; 8:35-78.

13. Yoshioka M, Matsushita $\mathbf{T}$ and $\mathbf{Y}$ Chuman Inverse Association of Serum Ascorbic Acid Level and Blood Pressure or Rate of Hypertension in Male Adults Aged 30-39 Years. Intern. J.Vit. Nutr. Res. 1984; 54: 343-7.

14. Salonen JT, Salonen RM, Thanainen M, Parviainen R, Sepparen M, Kantola K, Sepparen K and R Rawrama Blood Pressure, Dietary Fat and Antioxidants. Am. J. Clin. Nutr. 1988; 48:1226-1232.

15. Choi ESK, Jacques PF, Dallal GE and R Jacob Correlation of Blood Pressure with Plasma Ascorbic Acid. Nutr. Res .1991; 11:1377-1382.

16. Stanton JL, Braitman LE, Riley AM, Khoo C and JL Smith Demographic, Dietary Life Style and Anthropometric Correlates of Blood Pressure. Hypertension. Nutr. Res. 1982; 4(111):135-142s.

17. Joffres MRM, Reed DM and K Yno Relationship of Magnessium Intake and other Dietary Factors to Blood Pressure: The Honolulu Heart Study. Am. J. Clin. Nutr. 1987; 45:469-475.

18. Osilesi O, Tront J, Ongunwole $\mathbf{O}$ and EE Glover Blood Pressure and Plasma Lipids During Ascorbic Acid Supplementation in Borderline Hypertensive and Normotensive Adults. Nutri. Res. 1991; 11:405-412. 
19. Jacques PF A Cross Sectional Study of Vitamin C Intake and Blood Pressure in the Elderly. Intern. J. Vit. Nutr. Res. 1991; 252-255.

20. Kurl S, Tuomainen TP, Laukkanen JA, Nyyssonen K, Lakka T, Sivenius J and JT Salonen Plasma Vitamin C Modifies Association Between Hypertension and Risk of Stroke. Stroke 2002; 33(6):1568-1573.

21. Unknown Tue August 231999 New Orleans (AP)

22. Glavin GB Ascorbic Acid and Cold Restraint Ulcer in Rats: Dose-response Relationship. Nutr. Reports. Inter. 1983; 28:705-707.

23. Barnes MJ, Constable BJ, Morton LF and E Kodic Studies In Vivo on the Biosynthesis of Collagen and Elasitin in Ascorbic Acid Deficient Guinea Pigs: Evidence for the Formation and Degradation of a Partially Hydroxylated Collagen. Biochem. J. 1970; 119:575-85.

24. Saood M, Amunthathy S and RP Sheldon Regulation of Prolyl and Lysyl Hydroxylase Activities in Cultured Human Skin Fibroblasts by Ascorbic Acid. Biochem. Biophys. Res. Commun. 1981; 101:868-875.

25. Saood M, Shingo I, Gail RJ, Arinthathy S and RP Sheldon Collagen Synthesis in Cultured Human Fibroblasts. J. Invest. Dematol. 1983; 81:158-162.

26. Yu RT, Kurata M, Kin K and N Arakawa. The Behaviour of L-Ascorbic Acid in the Healing Process of Dorsal Wounds in Guinea Pigs. J. Nutr. Sci. Vitaminol. 1999; 27:207-211.

27. Shilotri PG Glycolytic Hexose Monophosphate Shunt and Bactericidal Activities of Leukocytes in Ascorbic Acid Deficient Guinea Pigs. J. Nutr. 1977; 107:1507-1512.

28. Shilotri PG Phagocytosis and Leukocyte Enzymes in Ascorbic Acid Deficient Guinea Pigs. J. Nutr. 1977; 107:1513-1517.

29. Stankove L, Gehandt NB, Nagel L and RM Bigley Ascorbate and Phagocytic Function Intect. Immun. 1975; 12:252-256.

30. Sardler JA, Gallin JM and I Vaughan Effects of Serotonin, Carbamyl Choline and Ascorbic Acid on Leukocyte Cyclic GMP and Chemataxis J. Cell. Biol. 1975; 67:480-484.

31. Thomas WR and PG Holt Vitamin C and Immunity: An Assessment of The Evidence. Clin. Exp. Immunol 1978; 32:370-379.

32. Hayward AR, Harvey BA and MJ Leaonard Delayed Separation of the Umbilical Cord, Widespread Infections, and Defective Neutrophil Mobility. Lancet. 1979; 1:1099-1101.

33. Dieter MP Further Studies on the Relationship Between Vitamin C and Thymic Humoral Factor. Proc. Soc. Exp. Biol. Med. 1971; 136:316-322.

34. Smithard DJ and MJS Longman Vitamin C and Drug Metabolism. B.J. Med. 1977;1029-1030.

35. Smithard DJ and MJS Longman The Effect of Vitamin Supplementation upon Antipyrine Metabolism in Man. Am. J. Clin. Nutr. 1978; 35:917-924.

36. Trang JMJ, Blanchard KA, Coward G and G Marrison The Effect of Vitamin C on the Pharmacokinetcs of Caffeine in Elderly Men. Am. J. Clin. Nutr. 1982; 35:487-494. 
37. Wilson J, Van T, Boxtel CJ, Alavan G and F Sjoqvist Failure of Vitamin C to Effect the Pharmacrokinetic Profile in Antiyprine in Man. J. Clin. Pharmacol. 1976; 16:265-270.

38. Holloway D, Mutton ESW, Peterson FJ and WC Saune Lack of Effect of Sub Clinical Ascorbic Acid Deficiency upon Antipyrine Metabolism in Man. Am. J. Clin Nutr. 1982;35:917-924.

39. Wade AE, Wu B and PB Smith Effects of Ascorbic Acid Deficiency on Kinetics of Drug Hydroxylation in Male Guinea Pigs. J. Pharn. Sci. 1972;61:1205-1208.

40. Sato PH and VG Zannoni Stimulation of Drug Metabolism by Ascorbic Acid in Weaning Guinea Pigs. Biochem. Pharmacol. 1974; 23:3121-3128.

41. Powers HJJ, Whitehead R, Downes D, Dighton D and $M$ Perry An Investigation in the Effect of Different Intakes of Vitamin C on Drug Metabolism in Gambian Men. Intern. J. Nutr. Res. 1990; 61: 1351-1362.

42. Johnston CS, Cartee GD and BE Maskell Effect of Ascorbic Acid Nutrition on Protein-Bound Hydroxyproline in Guinea Pig Plasma. J. Nutr. 1985; 115:10841093.

43. Mevia PS, Omaye T and RA Jacob Urinary Hydroxyproline Excretion and Vitamin C Status in Healthy Young Men. Am. J. clin. 1990;51: 644-648. 